\title{
CAUSES AND CONSEQUENCES OF THE CURRENT MIGRATION CRISIS IN EUROPE AND ITS SECURITY REPERCUSSIONS
}

\author{
Dragan TRIVAN, PhD \\ Faculty of Business Studies and Law, \\ University Union Nikola Tesla - Belgrade \\ Email: dtrivan@gmail.com \\ Milan MILOŠEVIĆ, PhD \\ Faculty of Business Studies and Law, \\ University Union Nikola Tesla - Belgrade
}

\begin{abstract}
:
Migration movements have been occurring during the entire history of mankind, while the main reason for abandoning national country or ethnic community was quest for better life and/or rescue from persecutions and violent conflicts. Unlike legal migration, that takes place according to the laws of the migrants' country of origin and destination country, there is illegal migration that reflects special circumstances and that is defined as each movement of the population from one country to another that does not take place under the laws of those countries, including illegal stay of foreigners in a given country. Recently, European countries and, in particular, the Member States of the European Union and the Western Balkan States (states in transition), are facing migrant and refugee crisis, caused by uncontrollable and outrageous volume of migrants' arrival. The causes of the current migrant crisis in Europe are different, but also very similar to previous: escape from the war suffering, extremism and terrorism, the search for better life, abandonment of failed and non-functional governments, etc. The major migration flows from The Near, the Middle East and Africa are directed towards highly developed countries and areas, whereby the Member States of the European Union are the most desirable, and most easily attainable destination. Mass illegal migration to Europe after 2014, regardless of the security measures taken and introduced legal restrictions, have heavily threatened border control and surveillance and border security, while migrant crisis in some EU Member States have adversely affected interior security, thus political and economic situation of those countries. Obviously, the institutions of the European Union have failed to recognize security risks of uncontrolled migration, while partial boost in border control on the eastern border of the Union has not reached the expected outcomes. Aggravating circumstance in solving current refugee crisis was and still
\end{abstract}


is the lack of common procedures, the absence of solidarity, and conflicting political views on the issue by the EU countries. risks.

Keywords: migrant and refugee crisis, the European Union, the Western Balkans, security

\section{Introduction}

The European migrant-refugee crisis is umbrella term for a series of events and incidents related to the mass arrival of refugees and migrants from Asia, Africa, and the Middle East during 2015 and 2016; mass of people seeking the asylum in the countries of the European Union. In the years before, the crisis had been mainly manifested on the Mediterranean coast of Italy, where number of illegal migrants were coming by ships and boats, in a series of cases, unsuccessfully, and what has led to mass deaths (Townsend, 2015). After 2014, the most massive influx of refugees and migrants is noted in the Balkans, which is a transit route from Turkey towards the developed countries of the European Union.

The European population is among the oldest populations in the world. In fact, the average age of the population of the European Union in 2010 was 39.8 years, where among the Member States of the Union, the highest average age was in Germany (44.2). Total average of the population 65 years older was 16\%, while the population 80 and over was 4.1\% (European Commission, 2014). The continuous increase in the contingent of the old population on one side and a decline in working-age population on other side, imposes a series of economic and social challenges to European societies (Arsenović and Solarević, 2016). Looking from this perspective; could the large number of refugees and migrants, mostly younger population, it be turned into an advantage when it comes to demographic challenges regarding the population aging? However, we should bear in mind several cultural and social differences that must be overcome in order to integrate immigrated population in new social, economic, and political settings.

Specific religious and cultural customs of immigrants are unacceptable for the environment they are coming to, and they are, too, challenging the legal systems of European countries. In such situations, enforcement of current applicable laws means endangering fundamental rights and freedoms arising from cultural and religious heritage of migrants. If migrants and refugees conflict the applicable legal system in the European Union, this can only be resolved if both sides are willing to compromise: either in terms of respect the positive laws or loosening up on immigrants' habits and customs. Both cases violate current principle of security. In the first case, it is about the disruption of the legal system, and in the last instance, the security situation in general, and in the other case it is about the breach of the human rights of immigrants.

The European political establishment was initially benevolent towards refugees from Syria, Iraq, and Afghanistan, but soon afterwards, there was a xenophobic reaction of politicians in EU Member States. Attitudes towards migrants have become a subject of sharp disputes between 
certain Member States, notably between Germany on the one side, and Hungary, Slovakia, and Poland on the other (Stevović and Crnobrnja, 2015).

In the last few years, the migrant crisis raised two conflicting conceptions of European multiculturalism. According to one concept, the essence of the multiculturalism of the old continent is its openness for returning of postcolonial non-European religious and cultural experiences. Another concept calls for inner-European ideal of multiculturalism and multinationalism. By this notion, Europe is inside an open society which historic formed identity and the roots of the character should be kept from mechanical disruption, as well as from an invasive demographic inflow from other continents and non-Christian religions, particularly Islam. This notion assumes that Europe has a notable Christian identity.

When it comes to the Republic of Serbia, and the Balkans in general, there are traditionally different problems concerning illegal and forced migration; its extent and intensity, as well as the impact on the vulnerability of human rights of refugees and migrants. It has always depended on the number and structure of persons seeking asylum or transit pass, reasons for request, country of origin, their racial, national, or religious affiliations, as well as on national legal framework, and economic, social, and political circumstances.

\section{Causes of the European Migrant Crisis}

Migrant and refugee crisis, which, in the last few years, has caused serious crisis in relations within the European Union, primarily is caused by the wars and upheavals in the Mediterranean and the Middle East Arab countries, but also by unclear interventions of the West in throwing down the dictatorial regimes during so-called The Arab Spring. Protests against Arab authoritarian regimes have initially been greeted with sympathy in Europe, but without clear interest of the European Union and the recognition of possible adverse outcomes of these processes. Cood example is Libya, where the opposing armed formations received NATO air support, particularly by France, to combat the armed forces of Colonel Muammar Gaddafi. However, after throwing down the regime, there was no sufficient support from the EU in building up a post-authoritarian society, and Libya, ended in clashes between armed Islamist factions, became a space for invasion of an ISIL jihadists and a key point of instability in North Africa. Similar happened in Egypt, and especially later in Syria (Tadić and Associates, 2016).

On March 15, 2011, in the Syrian cities, Damascus and Aleppo, mass anti-government demonstrations took place, the first armed conflict broke out a few days later in the southern Syrian town, Daraa, where the snipers shot the police, medical personnel and civilians (Anderson, 2017). In restoring the order in Daraa, Syrian army has joined, cordoning off the city. Only first few months of fight claimed the lives of more than 80 Syrian soldiers (Narwani, 2014). This has marked the beginning of the civil war that devastated the country and killed more than 400,000 people. Over the past seven years, the parts of Damascus, Aleppo, and Palmyra one of the world's most important archaeological sites, have vanished. In the fighting, Daraa, Deir al-Zour, Hama, Homs, Idlib, Maaloula, Eastern Ghouta and other cities were destroyed, (Bartlett, 2016). 


\section{Security}

Before the war conflict, Syria had population of about 23 million. During the war more than half were displaced. It was expected that the Syrian civilians will run away from areas under control of terrorist groups - jihadists who made harsh public executions and declared war on religious minorities and other "nonbelievers". About a million and a half of Syrian refugees escaped to Turkey, and half a million in Jordan and Lebanon. In 2015, hundreds of thousands of Syrians managed to reach EU vial Balkan route. Nevertheless, during the war, the vast majority of refugees still remained in Syria in the areas under control of the Syria Government. On December 31, 2016, UNHCR estimated the number of Syrian refugees to 4.8 million, and the number of internally displaced persons in Syria to 6.6 million (IDMC, 2016).

Otherwise, after the American invasion of Iraq, Syria has accepted about two million Iraqi refugees. UNHCR survey conducted at the end of 2010 has shown that a significant number of these refugees did not want to return to Iraq. Syrian Arab Red Crescent estimates that in mid-2014 there was still 450,000 Iraqi refugees in Syria. Even five years after the war expansion, thousands of Iraqi refugees were still occasionally escaping to the "relative safety" of Syria, especially in the province of Hasakah (Hassan and Alazroni 2016).

In the spring of 2015, the north of Syria was invaded by forces of Jaysh al Fateh, Jabhat al Nusra Alliance and "Free Syrian Army" (FSA) financed by Turkey, Qatar, and Saudi Arabia. The Islamist militias have then taken a greater part of the Idlib and Hama, expelling many people to the south, to Homs and Damascus, and to the west, toward the Syrian Mediterranean coast, and to the north, toward Turkey. In May 2015, ISIL jihadists occupied Palmyra, and in the same year, from July to September, Turkish forces have carried out a series of attacks on the Kurds in the border region with Syria. After beginning of Russian air operations in 2015 against Islamist forces, the situation on the ground has changed, and ISIL jihadists are brought to the brink of military collapse and were almost expelled from Syria. However, fighting between the Syrian Army loyal to President Assad and the remains of various rebel structures supported by the United States have continued (Anderson, 2016). We should bear in mind that share in responsibility for the conflicts, displacement of population from Middle East, and European migrant crisis have USA, as well as EU, which supported the war operations in Afghanistan, Iraq, Libya, and Syria (Nevradakis 2016).

Widespread notion, particularly propagated by the USA, is that on the wave of the "Arab Spring" in 2011 peaceful national protests in Syria took place, and after several months of repression by the regime of Bashar al-Assad, protesters had no other choice but to rise up arms and stand against the forces of the Syrian Government in order to defend themselves. However, some independent observers questioned the credibility of such a statement. Namely, in Syria in early 2011 there were large protesting gatherings, some of which were against the Government and some in support of al-Assad. Most participants in these groups had not planned an armed uprising. Saudi Arabia's official, Anwar Al-Eshki, admitted in 2012, that his country has equipped with weaponries radical Islamists in Syria (Al-Eshki, 2012). Some of the Western governments and media have supported jihad's version depicting Syria's conflict as libertarian revolution. Saudi support of Islamists in Syria, and the U.S. goal for regime change in Damascus are not unrelated phenomena. In fact, U.S. Secretary of State Condoleezza Rice yet in 2006 
announced plans for a "new Middle East", to be achieved through "creative destruction" (Levine, 2006). The US intelligence community was aware that behind the escalation of violence in Syria are standing Islamic extremists, but in 2014, it was concluded that the creation of "an announced or unannounced Salafist Caliphate in eastern Syria... is what is needed in order to isolate the Syrian regime "(DIA 2012).

Due to abuse of Resolution 1973 of UN Security Council from 2011 (request to protect civilians in Libya, which NATO used as a cover to overthrow Libyan regime), the Russian Federation and China have refused to support similar resolution of UN regarding Syria. The event for the adoption of such a resolution were accusations of alleged chemical weapon attacks on East Ghouta in August 2013, when the jihadists Jabhat al Nusre (Al Qaeda) and Jaysh al-Islam, at the time controlling the eastern suburban areas of Damascus, accused government forces. The New York Times then supported Washington's claims that the "only forces able to conduct such an act were Syrian Government forces" (Gladstone and Chivers, 2013). Several US intelligence leaders, however, said that for the attack, organization Jabhat al Nusre, should be held responsible, which members earlier had certain amount of gas sarin when they were captured in Turkey (Hersh, 2013). There is a remaining claim that nerve agent sarin was used in Eastern Ghouta, but without fixed number of casualties, and unproven charges against Syrian army. This clam leads to conclusion that the incident was one in a series of provocations launched by the Islamists, to garner support from the West.

During 2014 USA has changed its agenda in Syria, abandoning the strategy of "humanitarian intervention" in favor of "protective interventions". The administration of Barack Obama, who earlier announced that administration is helping the groups of "moderate opposition" in Syria, has proclaimed that it will provide support to the forces on the ground ready to fight against the extreme jihadists Jabhat al Nusre and ISIL. After that, answering to the calls from Iraqi Government, the US renewed its presence in Iraq, with the mission to plan operation in Syria from there (Rothman 2014).

\section{Migration Crisis and European Union}

The population of the European Union has faced one of the largest migrant crisis in 2015 and 2016, whereby more than a million people have been seeking the asylum in European countries. The largest number of asylum applicants came from Syria, then Afghanistan, and Iraq. One of the basic demographic challenges caused by refugee crisis is related to the fact that the majority of migrant population are young people. Most of them men, one half declaring single status and second half stated married status (Reach, 2015).

UNHCR analysis from September 2015 indicates seven major reasons for directing the refugee wave from Syria to the European Union. First was the loss of hope that the situation will change for the better in their country or that any solution to the war conflict is in sight. In second place is increasing poverty of Syrian refugees who have found shelter in Lebanon, Egypt, and Jordan and then got in a situation where they couldn't obtain even the simplest necessities. The 


\section{Security}

third is a realistic lack of employment opportunities for refugees from Syria in Arab countries. The fourth reason for the mass departure to Europe is lack of assistance and health care. The fifth were obstacles to the update of refugee status in Lebanon and Jordan. The sixth reason for migration was limited opportunities for education. Finally, movement of the refugee wave towards Europe occurred due to the instability in Syria's surroundings, or fear of the war escalation in these areas and negative reaction of the local population (Tadić and Associates, 2016:21-22).

There are also allegations that refugee wave towards the European Union was not spontaneous, and that the idea of great migrations to Europe has already existed. Supporters of this statement are pointing to the article in Brussels magazine Europe's World, where William Lacy Swing, the Director General of the International Organization for Migration (IOM) and Michael Diedring, Secretary of the European Council on Refugees and Exiles (ECRE) are talking about the vision of migration as a process that should be controlled, thus, not a problem to be solved (Maystadt, 2017). According to these allegations, if promoted humanely, through security, order and dignity, migration has a number of advantages, as it provides many opportunities, increase incomes and living standards and allows people to educate themselves and pursue their ambitions. In this context it was highlighted that migration has reduced or even changed aging trend in many of the European countries and stopped unbearable relation between working and aided population. (Stefanov, 2017). Such notions then pulled series of actions and statements by German officials and certain number of non-government organizations that were actively supporting war refugees and economic immigrants towards the European Union.

According to some theories, behind the last wave of migration from the Middle East stands the strategic project of depopulation of Syria, the country that should be left without an educated and working population. $\mathrm{On}$ the other hand, some left-oriented theorists believe that migrants are creating a labor army reserve of the EU, always needed to employers to lower the wage and labor rights in general. Finally, there are authors who see a long-term strategy of Europe Islamisation.

\section{Migrant Routes to Europe}

According to the International Organization for Migration (IOM), after the biggest wave in 2015, when around 1.2 million migrants came to the borders of the Union, by the end of 2016, additional 400,000 refugees arrived in the European Union. Most of them came through Greece and the Western Balkans, or by sea to Italy. IOM indicates that 2016 was the most dangerous for migrants and refugees, considering that in 2016 more migrants have sunk in the Mediterranean Sea than in 2015-4,220 compare to 3,780 (IOM, 2017).

In 2017, on the main migration route through Greece, it was recorded a decrease in number of migrants by almost $80 \%$ from 2016 , mainly due to increased security measures by Turkish authorities. According to the European Border and Coast Guard Agency (Frontex) during 2017, about 205,000 illegal migrants entered the territory of the European Union, which is about 60\% less comparing to 2016. However, this number is still much higher than the average number in the years before the migrant crisis (around 100,000 illegal migrants annually). The UNHCR report 
from February 2018 notes drastically degraded conditions in overcrowded migrant camps in Greece, which at night time are off limits for women and children becoming so called "no-go areas".

Frontex data indicate that during 2017, near 119,000 people from African countries tried to get illegally to Italy from the shores of Libya by ships and boats. An effort to get another migration route Turkey-Greece, 42,000 African immigrants were discovered and another 23,000 tried to reach the borders of Spain from the territory of Algeria and Morocco. While the number of illegal immigrants from Africa to Italy is declining, on the migrant route to Spain is twice as bigger then in 2016 (EURACTIV, 2018).

From November 2017 to February 2018, UNHCR evacuated around 1,000 the most vulnerable African migrants, 300 of them to Italy. The others were transferred to Niger to wait for permanent transfer location (most likely in Europe). This UNHCR mission was not well accepted in Italy, where increased anti-migrant attitude and leaders of some of the major political parties, such is Lega Nord, threatened with mass migrant's deportation (Lyman, 2018).

\section{The European Union Reaction to Migration Crisis}

Some Member States of the European Union, such as Germany, Austria, Sweden, and Denmark, have, at the highest of the migrant crisis in 2015, tried to resolve the problem, with temporary border controls, that could also, remain permanent.

In September 2015 the European Stability Initiative (ESI) has worked out a plan according to which Germany needs to commit to settle 500,000 refugees from Turkey annually, along with other EU Member States on a voluntary basis. At the same time, Turkey should again accept everyone who comes to the Greek Islands, on the basis of the concept of safe third country. In accordance with this concept, the refugees who arrive to Greece are interviewed if they want asylum, and if they answer affirmative, the Greek authorities must examine a request for asylum and decide whether Turkey is a safe place for a particular asylum applicant. If it is determined that Turkey is a safe country, asylum seeker can be returned (Alkousaa and Associates, 2016).

In March 2016, the EU signed an agreement with Turkey on returning migrants on the path to developed countries of the EU to Turkey; all new irregular migrants crossing from Turkey into Greek islands as from 20 March 2016 will be returned to Turkey. The Agreement was followed by the EU loan approval to Turkey worth three billion euros, with the notation that such credit tranches will repeat in the future. Under the Agreement, Turkey pledged to take back all irregular migrants who have crossed into Greece, including persons fled from Syria, with the closure of the Balkan route, if the Member States of the Union allow the submission of asylum applications of the portion of Syrian refugees. Turkish President Recep Tayyip Erdogan, meanwhile, continued to blackmail the European Union, demanding no-visa status for Turkey and threatening with new refugee waves to Europe (Skinner, 2016). Turkey, at that moment, had already on its territory a "reservoir" of over 2.2 million refugees (Bajekal, 2015).

Announcement of measures stated in the Agreement with Turkey faced opposing notion by the countries of the Visegrád Group (Poland, Czech Republic, Hungary, and Slovakia) that refused 


\section{Security}

admission of migrants based on distribution share. We should consider that these countries, as well as other countries of Central Europe, in the past were not colonial powers and have traditional resistance to immigration from non-European countries (Wintour, 2017).

When it comes to Germany, there are two important political implications of the refugee crisis. The first concerns the period when there was welcoming climate for refugees. In the meantime the situation has changed in the direction of increased skepticism and fear, supported by two extreme right-oriented movements PEGIDA (Patriotic Europeans Against the Islamisation of the West), which organized a number of anti-migrant demonstrations in different cities of Germany, and populist party AFD (Alternative for Germany), which became the third political force in the country on a wave of xenophobia and Islamophobia (Mansfield and Pallenberg, 2016).

In February 2018, Matteo Salvini, the leader of the Italian right-wing and populist party of Lega Nord and coalition partner of Forza Italia, led by former Prime Minister Silvio Berlusconi, announced that in case of winning the upcoming parliamentary elections, during the next five years term, as many as 500,000 migrants and refugees will be deported from Italy, as a part of comprehensive measures in the field of control, regulation, and restrictions on immigration in the country. Currently, there are about 180,000 persons in Italy seeking asylum, most of whom reside in the greater area of Rome. Despite criticism expressed by human rights groups, the French Government proposed legislation changes in late February 2018 in the field of immigration and asylum which would, among other things, allow the extension of detention of illegal migrants up to 90 days (currently 45), shorten the deadline for the asylum application, while illegal border crossing would be considered as a crime sentenced up to a year of imprisonment and deportation from the country. Additionally, in 2017 there were close to 100,000 persons seeking the asylum in France. Moreover, there are allegations that Sweden has become the European base of the international Islamic terrorist networks, i.e. hundreds of immigrants in this country were linked to ISIL in a variety of ways. Under the supervision of the ISIL new radical Islamists, mostly in the socalled "no-go zones", in the suburbs of Malmö and Stockholm are recruited (Tomlinson, 2018). As a confirmation of these theses, an example of Uzbek Rakhmata Akhilova, is used. On April 7, 2017, in Stockholm square he ran with his truck over a crowd of people and activated improvised explosive device, killing five and injuring 10 people. Akhilov, who supported the establishment of the Islamic Khalifate, arrived in Sweden in 2014 while his request for asylum was rejected in 2016. The leaders of the right-wing party, Swedish Democrats, made the claim that the budget expenditures of that country for refugees and asylum seekers in 2018 will be around 5 billion euros (6.6 billion euros, is the annual budget for Defense). This, as well as the risk of importing terrorism, according to them, requires abandoning the current policies toward immigrants ("a humanitarian superpower"), and a drastic tightening of the legal requirements for the entry and residence permit in Sweden. Nevertheless, in 2015 at the peak of the migrant crisis in Europe, about 163,000 persons requested asylum in this country. According to the Czech expert for security, Lucas Visingra, Europe is going to face more ruthless terrorist attacks by the new generation of Islamic terrorists, made up of the defeated and escaped members of the ISIL. The main problem, according to him, is that the 
political elite in Europe do not realize the volume of danger threatening European countries (Visingr, 2018).

Migrant crisis provided great opportunity to the extreme right oriented and populist parties in many European countries to benefit in politics, playing on endangered identity card. At the same time the party of the political center have seen the crisis as if it is a natural disaster believing that it will pass and not elaborating a strategy to integrate more than a million people who have found themselves on the territory of the European Union.

\section{Migration Crisis and the Western Balkans}

We can talk about several "triggers" of European migration crisis started in 2015. First, the Macedonian authorities made the decision to permit transit of refugees, opening so called "the Balkan route", which is shorter and less dangerous than the Mediterranean route. Second important aspect was the perception of migrants, based on statements made by German Chancellor Angela Merkel that the refugees from Syria will not be returned back.

Faced with rapid growth in the number of illegal migrants and a refugee crisis, Hungary has built a fence on the borders with Serbia and Croatia in order to physically secure and prevent the entry of migrants to its territory. Simultaneously, with strengthening of the refugee wave on Balkan route, the Hungarian Army and police sent its forces at the border applying repressive measures towards illegal migrants. Additionally, Hungary adopted legislation suspending certain European regulations, defining normative basis for more repressive approach to illegal migration, including punishment for illegal border crossing, authorizing the army to conduct so-called nonlethal force. Justification for these measures was the need of Hungarian citizens for protection of state borders and country defend policy, and that the refugee wave from the Middle East threatens European Christian heritage (Tatalović and Malnar, 2015).

In the late 2015, Austrian and German governments have aligned "secret plan for the Balkans" aiming to stop the wave of migrants before the migrants reach their borders and the retention of refugees in further south, preferably in Greece. In compensation for the migrants' management, Greece would have gained a significant financial support, with the possibility of part of the debt forgiveness. In case of failure of this option, Germany and Austria have expressed willingness to provide financial assistance to all the countries on the Balkan route for immigrant selection; allowing pass to the Western Europe only to eligible immigrants, those who meet requirements for asylum, and returning everyone else back to the country of origin. However, the decrease in migrant waves from the Middle East have already put the program in mid-2016 ad acta.

The European Union was unable to offer a comprehensive approach to existing situation, primarily because of the substantial differences among Member States. Namely, the priority of the countries on the Balkan route was to accelerate the passage of refugees and migrants through their territories, and any attempt to limit this process provoked loud diplomatic reactions of neighboring countries. Relations between Croatia and Serbia, as well as Croatia and Hungary, have 


\section{Securitity}

aggravated the circumstances of secret transfer of groups of migrants across the border line. On the other hand, certain EU Member States (Hungary, Slovenia, and Austria) have decided to build a fence on the border to stop the flow of migrants (Zara, 2016).

\section{Characteristics of Migration Waves across Serbia}

During 2015, near 600,000 non-EU refugees and migrants have entered the Republic of Serbia. Several factors affected this refugee wave: the dynamics of the flow of migrants into Greece from Turkey, the situation in Macedonia with the occasional closing of the borders, rigid policies of Hungary towards the refugees, as well as the views of the European Union and EU Member States on acceptable modalities for resolving the migrant crisis. Situation on the field has changed frequently, in terms of number of newly arrived migrants and refugees, their movement route, borders (im) permeability, and efficiency of the authorized government institutions. The vast majority of migrants have seen the Republic of Serbia only as a transit country.

Balkan migrant route across Serbian territory has changed its paths during 2015 and 2016. The sole constant was the main entry point - border with Macedonia, while entries from Bulgaria began to be recorded during the summer of 2015. Also, there have been significant changes in terms of exit points - the first months of migrant wave is solely recorded in the direction towards Hungary, while over the last months, predominantly towards the borders of the Republic of Croatia (Jelačić, 2016).

In addition to the existing asylum centers in Serbia, along with increasing numbers of migrants several other so-called acceptance-transit centers are opened: in Preševo, including checkpoint for emergency admission in Miratovca, Kanjiža (active until September 15, 2015), Subotica, Šid (near the railway station, so-called "Grey House", Adaševci, and Principovac) and in Dimitrovgrad. Certain potential sites for opening additional centers in the event of an increase in the number of migrants and refugees were selected. Belgrade has long been a major point on a movement map, although in Belgrade was never formally established an acceptance center, despite the fact that until September 2015, 100 up to 1,000 migrants and refugees wandered daily, out in the open space.

In situation of complete closure of Hungarian border and the proclamation of the Republic of Serbia as a safe third country, with the UNHCR's decision on Macedonia as a unsafe third country, Serbia faced the challenge of deciding on asylum requests, i.e. the provision of international protection of the number of persons that is beyond its capacity. A big shift was the Decision on issuance of certificates of entry into the territory of the Republic of Serbia for migrants who come from countries where their lives were in danger (a transit certificate) adopted by the Serbian Government in September 2015 which came into force in early 2016.

After signing the Joint Statement of the Chief of police in Zagreb in February 18, 2016, Serbian authorities dismissed the practice of issuing transit certificate. The Joint Statement called for the issuance of a single refugee registration form, issued in Macedonia, that when in transit is stamped by all the countries - parties of the agreement. 


\section{Secuurity}

From the moment of criteria alignment among the states of Balkan route, made by states' police departments, the number of those who have been denied entry into the Republic of Croatia and the continuation of the journey have increased. Government authorities allowed them to either apply for asylum, or to be returned over Preševo to Macedonia to obtain the proper documentation for entry into EU States, or to be returned to Bulgaria, if Bulgaria was the enter point to Serbia. Due to such a practice, number of individuals with unregulated status were recorded on the territory of the Republic of Serbia. A problem of accommodation and the provision of assistance to this category of migrants has occurred, given that they haven't shown a willingness to get into process of asylum, thus the right for accommodation in one of the existing asylum centers.

During the migrant crisis, Serbia was trying to follow the policy of the EU, when it was clear and unequivocal, but when it wasn't like that, Serbia first followed the suggestions of Germany, who advocated for allowing refugees, than Austria, which supported the closing of the Wester Balkans route. Searching for a solution in the climate of a lack of unique European policies, Serbia has followed differently articulated policies of individual Member States of the EU, facing the problems which were not well understood in Brussels (Lutovac, 2016).

\section{Conclusion}

Conflicts over the past decade in failing countries of the North Africa, the Middle East and Central Asia (Libya, Syria, Iraq, Afghanistan), forced millions of people to flee their homes. In 2015 in Europe there has been a massive and complex migration wave across "Balkan route" and by Mediterranean Sea, not seen since 1945. This wave put together refugees fleeing from the wartorn Syria and northern Iraq and economic migrants.

The European Union, too, has indirectly encouraged those processes. On the one hand, the economic situation in the Arab countries of the Mediterranean significantly deteriorated after 2008 because of the economic stagnation and crisis within the EU, and above all, because of decrease in exports to the Union market, which was and remained their main market. On the other hand, the situation in Arab countries was further disadvantaged by the requirements of the European Union for the implementation of reforms of European standards, according to the principle "more for more", which means more reform for more trade with the Union. In addition, liberalization measures on the internal market, on the basis of signed agreements with the European Union (FTA), followed by reduction in social measures, has made the situation in the countries of the East and South of the Mediterranean more difficult. Previous practice of state subsidies in food and fuel in the Arab countries has become a difficult to sustain after 2008, which was one of the main triggers of the protest, along with rooted corruption and incompetence of the ruling elite to deal with economic problems.

"Arab spring", which culminated in 2011, disabled appropriate response against Islamic terrorism. In fact, demolition of authoritarian regimes in Iraq, Libya and Egypt did not lead to the establishment of democratic systems in these countries, in contrast it has led to instability and opened a space for the expansion of terrorism and Islamic fundamentalism. The most tragic 


\section{Security}

consequences were in Syria, where authoritarian regime have not been taken down, while bloody civil war has started. Use of jihadist organizations for throwing down Syrian regime, which initially was supported by USA and its Middle East allies, particularly Saudi Arabia, Qatar, and Turkey, had a boomerang effect, causing regional instability.

Considering that $80 \%$ of refugees which found themselves at borders of the EU in 2015 arrived by sea from Turkey, it was evident that the main problem related to their aid and support is in the Turkey. The Agreement between the European Union and Turkey from March 2016, contributed to shutdown of the "Balkan route", which showed that the Turkish authorities have mechanisms to manipulate; reducing or increasing the transit of migrants and refugees to Europe. There is no direct connection between the involvement of the Russian Federation military forces in Syrian war and the influx of refugees and migrants to Europe. Contrary, one can speak of a negative correlation, because from then on, there was an increasing trend of returning internally displaced persons to their homes in Syria, given the upturn of the war progress and the victorious advancement of the Syrian Government's forces in the liberation of territories that were previously controlled by jihadists.

Reactive and successive closing of the state borders of Member States of the European Union that were on the path of migration movement was contradicting to the principles of the Schengen Agreement on visa-free regime and no-borders policy in the European Union. Migrant crisis highlighted the failure of the internalization of the European values within the European Union. In fact, political discourse, behavior, and activities of some of the EU Member States have to a large extent violated the rights and freedoms that the generation of European citizens were proud about.

The Republic of Serbia, as a state surrounded by four Member States of the European Union, and that poses as the guardian of the Schengen border system in Europe, at the same time, is the transit country for many citizens of Afro-Asian countries, which are escaping poverty, conflicts and suppression, trying to get to the developed European countries. For these reasons, Serbia is in a delicate position in two ways. As a country in the EU accession process, Serbia is required to protect its southern borders from illegal immigrants and potential terrorists, and on the other hand Serbia was demanded to carry out border policy that has elements of racism and that threaten some of the universal human rights.

\section{References}

1. Al-Eshki, A. (2012) "Syria - Daraa revolution was armed to the teeth from the very beginning", YouTube, 7 November 2012, http://www.youtube.com/watch?v=FoGmrWWJ77w (visited on 03.03.2018).

2. Alkousaa, R. et. al. (2016) "The Many Failures of the EU-Turkey Refugee Deal“. Spiegel Online, 26 May 2016. http://www.spiegel.de/international/europe/the-refugee-deal-betweenthe-eu-and-turkey-is-failing-a-1094339.html (visited on 19.03.2018).

3. Anderson T. (2016) "Rat u Siriji i evropska migrantska kriza“, PIS Journal, no. 3. 
4. Anderson, T. (2017) "The Dirty War on Syria". Global Research, 13 June 2017.

5. http://www.globalresearch.ca/the-dirty-war-on-syria/5491859 (visited on 11.02.2018).

6. Arsenović D. Solarević M. (2016) „Migrantska kriza - pretnja ili šansa starenju stanovništva Evrope". In: Konferencija "Hrvatsko-srpski odnosi u 20. veku: Izbeglice, prognanici i povratnici - Izazov za savremenu Evropu i zapadni Balkan". Novi Sad: Centar za istorijat, demokratiju i pomirenje.

7. Bajekal, N. (2015) "Why the E.U. Is Offering Turkey Billions to Deal With Refugees". Time, 19 October 2015., http://www.time.com/4076484/turkey-eu-billions-dollars-refugee-slow/ (visited on 07.03.2018).

8. Bartlett, E. (2016) "Western Corporate Media "Disappears" over 1.5 Million Syrians and 4,000 Doctors". Global Research, 14 August 2016. http://www.globalresearch.ca/westerncorporate-media-disappears-over-1-5-million-syrians-and-4000-doctors/5541005 (visited on 16.02.2018).

9. DIA (2012) „Intelligence Report - R $050839 Z$ Aug 2012". Judicial Watch, 18 May 2015. http://www.judicialwatch.org/document-archive/pgs-287-293-291-jw-v-dod-andstate-14-812-2/ (visited on 09.03.2018).

10. EURACTIV (2018) "Africans made two thirds of illegal arrivals to EU in 2107". EURACTIV, 21 February 2018. http://www.euractiv.com/section/justice-home-affairs/news/frontexafricans-made-two-thirds-of-illegal-arrivals-to-eu-in-2017/ (visited on 04.03.2018).

11. European Commision (2014), Population Ageing in Europe: facts, implications and policies. Brussels: European Commision.

12. Gladstone R. Chivers C.J. (2013) "Forensic Details in U.N. Report Point to Assad's Use of Gas". The New York Times, 16 September 2013. http://www.nytimes.com/2013/09/17/world/ europe/syria-united-nations.html?_r=0\&amp;adxnnl=1\&amp;adxnnlx=138738176655AjTxhuELAeFSCuukA70g (visited on 21.02.2018).

13. Hasan M. Alazroni Q. (2016) "Iraqis flee Mosul clashes for relative safety of Syria". UNHCR, 27 May 2016. http://www.unhcr.org/news/latest/2016/5/57482e0e4/iraqis-flee-mosulclashes-relative-safety-syria.html (visited on 10.02.2018).

14. Hersh S.M. (2013) "Whose Sarin?", London Review of Books, Vol. 35, No. 24, pp. 9-12.

15. IDMC (2016), Syria IDP Figures Analysis, 19 September 2016. http://www.internaldisplacement.org/middle-east-and-north-africa/syria/ (visited on 02.03.2018).

16. IOM (2017) Migrations Flows to Europe - Quarterly Overview. Geneva: International Organisation for Migration.

17. Jelačić, M. (2016), Izazovi migrantsko-izbegličke krize iz ugla OCD, Beograd: Grupa 484.

18. Levine, M. (2006) "The new creative destruction“.'AsiaTimes Online, 22 August 2006. http:// www.atimes.com/atimes/Middle East/HH22Ak01.html (visited on 20.02.2018).

19. Lutovac Z. (2016) "Migracije i evropske integracije Srbije". In: Stanovništvo, Vol. 54, br. 1 , str. 41-63. 
20. Lyman, D. (2018) „UN Importing African "Refugees" to Italy - By Plane". Newswars, 19 February 2018. http://www.newswars.com/un-importing-african-refugees-to-italy-byplane (visited on 09.03.2018).

21. Mansfield K. Pallenberg M. (2016) "They invited us - Refugee says Germany wanted migrants", The Express, 14 December 2016, http://www.express.co.uk/news/world/743487/ refugee-germany-angela-merkel-invited-syria (visited on 03.03.2018).

22. Maystadt, P. (2014) "How to bring labour mobility to Europe". Europe's World, 10 December 2014. http://www.friendsofeurope.org/smarter-europe/how-to-brimg-labour-mobilityto-europe (visited on 10.03.2018).

23. Narwani, S. (2014) "Syria: The hidden massacre". RT, 7 May 2014.

24. http://rt.com/op-edge/157412-syria-hidden-massacre-2011/(visited on 20.02.2018).

25. Nevradakis, M. (2016) "Human Rights Lawyer Francis Boyle on US War Crimes, the Refugee Crisis in Europe and More". Truthout, 4 April 2016. http://www.truth-out.org/news/ item/35486-human-rights-lawyer-francis-boyle-on-us-war-crimes-the-refugee-crisis-ineurope-and-more?tmpl=component\&print=1 (visited on 26.02.2018).

26. REACH (2015) Migration trends and patterns of Syrian asylum seekers traveling to the European Union-Assessment report. Geneva: REACH.

27. Rothman, N. (2014) „Dempsey: I know of Arab allies who fund ISIS". YouTube, 16 September 2014.

28. https://www.youtube.com/watch?v=nA39iVSo7XE (visited on 15.02.2018).

29. Skinner, A. (2016) "For Erdogan, migration crisis is an opportunity”. Politico, 18 November $2016 . \quad$ http://www.politico.eu/article/for-recep-tayyip-erdogan-refugee-crisis-anopportunity/ (visited on 20.03.2018).

30. Stefanov, M. (2017) „Imigracija i fingirana sinkopa europske politike elite“, Geopolitika news, 30. decembar 2017 http://www.geoplitika.news/analize/mario-stefanov-imigracija-ifingirana-sinkopa-europske-politicke-elite (visited on 18.03.2018).

31. Stevens D. (2017) "Asylum, Refugee Protection and the European Response to Syrian Migration", Journal of Human Rights Practice, Vol. 9, Issue 2.

32. Stevović M. Crnobrnja M. (2015) „Bezbednosna politika Evropske unije i aktuelna izbeglička kriza", Megatrend revija, Vol. 12, No. 3.

33. Tadić J. et. al. (2016) „Migracijska i izbjeglička kriza - sigurnosni rizici za EU“, Policija i sigurnost, Vol. 25, No.1.

34. Tatalović S. Malnar D. (2015) "Sigurnosni aspekti izbjegličke krize", Političke analize. Vol. 6, No. 23.

35. Tomlinson C. (2018) "Greek Migrant Camps Becoming "No-Go Areas" for Children and Women at Night". Breitbart, 13 February 2018.

36. http://www.breitbart.com/london/2018/02/13/greek-migrant-camps-becoming-no-goareas-children-women-night/ (visited on 08.03.2018).

37. Tomlinson, C. (2018) "Sweden Has Bacome a "Base" for International Radical Islamic Extremist Networks". Breitbart, 13 February 2018. 
38. http://www.breitbart.com/london/2018/02/13/expert-sweden-become-base-radicalislamic-extremists/ (visited on 08.03.2018).

39. Townsend, M.R. (2015) The European Migrant Crisis, Morrisville: Lulu Press.

40. Visingr, L. (2018) "Europe 's politicians do not want to admit the west is in a state of war". Voice of Europe, 16 February 2018.

41. http:/www./voiceofeurope.com/2018/02/security-analyst-europes-politicians-donot-want-to-admit-the-west-is-in-a-state-of-war/\#.WoLQ0JVre5U.twitter (visited on 03.03.2018).

42. Wintour, P. (2017) „EU takes action against eastern states for refusing to take refugees". The Guardian, 13 June 2017 http://www.theguardian.com/world/2017/jun/13/eu-takesaction-against-eastern-states-for-refusing-to-take-refugees (visited on 11.03.2018).

43. Žarin I. (2016) „Da lije današnja Evropska unija budućnost za Zapadni Balkan“. In: Budućnost EUiZapadni Balkan - pogled iz Srbije, Beograd: Fondacija Fridrih Ebert. 